\title{
Conivaptan and its role in the treatment of hyponatremia
}

\author{
This article was published in the following Dove Press journal: \\ Drug Design, Development and Therapy \\ 15 October 2009 \\ Number of times this article has been viewed
}

\author{
Jalal K Ghali' \\ Jareer O Farah ${ }^{2}$ \\ Suleiman Daifallah ${ }^{3}$ \\ Hassan A Zabalawi ${ }^{4}$ \\ Hammam D Zmily ${ }^{5}$ \\ 'Detroit Medical Center, Detroit, MI, \\ USA; ${ }^{2}$ Wayne State University/Detroit \\ Medical Center, Detroit, MI, USA; \\ 3John D Dingell VA Medical Center, \\ Detroit, MI, USA; 4,5Wayne State \\ University/Detroit Medical Center, \\ Detroit, MI, USA
}

\begin{abstract}
Hyponatremia is the most common electrolyte abnormality in hospitalized patients and is associated with increased morbidity and mortality. The recognition of the central role that arginin vasopressin plays in the pathogenesis of hyponatremia and the discovery that its actions are mediated by stimulation of $\mathrm{V}_{1 \mathrm{~A}}$ and $\mathrm{V}_{2}$ receptors have led to the development of a new class of drugs, the arginin vasopressin antagonists. Conivaptan is a nonselective $\mathrm{V}_{1 \mathrm{~A}}$ and $\mathrm{V}_{2}$ receptors antagonist that was the first of this class to be approved by the FDA for the management of euvolemic and hypervolemic hyponatremia. Its short-term safety and efficacy for the correction of hyponatremia have been established by multiple double-blind, randomized, controlled studies. Blocking the effects of arginin vasopressin on $\mathrm{V}_{2}$ receptors produces aquaresis - the electrolyte-sparing excretion of water - an ideal approach to correct hypervolemic hyponatremia. The nonselectivity of conivaptan offers a theoretical advantage for its use in heart failure that may merit further exploration.
\end{abstract}

Keywords: arginine vasopressin antagonist, conivaptan, heart failure, hyponatremia

\section{Introduction}

Hyponatremia is the most common electrolyte abnormality seen in hospitalized patients. Although recognized for almost a century, our understanding of hyponatremia remains incomplete and its management continues to represent a challenge. The presence of inappropriately elevated plasma level of arginine vasopressin (AVP) is well established in the vast majority of hyponatremic states, and the development of arginine vasopressin antagonists signaled the beginning of a new treatment option for hyponatremia. Conivaptan was the first such agent to be approved for this indication in euvolemic and hypervolemic states.

This article reviews the pathogenesis of hyponatremia and the pathophysiological basis for the development of conivaptan, its properties, the experience accumulated from clinical trials, and its current use and potential future role.

\section{Prevalence}

The prevalence of hyponatremia varies depending on the definition used, patient population, and the frequency of testing. ${ }^{1}$ When defined as $\leq 135$ milliequivalent per liter $(\mathrm{mEq} / \mathrm{L}$ or $\mathrm{mmol} / \mathrm{L})$, the prevalence was reported in 40,000 hospitalized patients at $28 \%$ on admission, with the development of hyponatremia in another $14 \%$ while in the hospital. ${ }^{2}$ However, figures as low as $5.5 \%$ have also been reported. ${ }^{3}$

In patients with heart failure, using this definition, a prevalence of $20 \%$ to $45 \%$ has been reported in several large registries..$^{4-8}$ The prevalence would be considerably higher,
Correspondence: Jalal K Ghali

Detroit Medical Center, Harper University Hospital, 3990 John R, Suite 9370, Detroit, Michigan 4820 I, USA

Tel + I 3 I3 745706 I

$\mathrm{Fax}+$ I 313 745 902।

Email jghali@dmc.org 
however, if a cutoff of $138 \mathrm{mEq} / \mathrm{L}$ were adopted to define hyponatremia, ${ }^{9}$ a level below which an increased morbidity and mortality was noted in this patient population. ${ }^{8}$

\section{Clinical manifestations}

The clinical manifestations of hyponatremia are related to osmotic water shift leading to increased intracellular fluid volume causing cerebral edema. Because the surrounding cranium limits expansion of the brain, intracranial hypertension develops and may cause brain injury. ${ }^{10-13}$ Therefore, symptoms are primarily neurologic and their severity depend on the rapidity of development of hyponatremia and its magnitude. ${ }^{10-13}$ Patients may be asymptomatic or they may develop symptoms such as malaise, headache, nausea, vomiting, lethargy, depressed reflexes and confusion. As the plasma $\left[\mathrm{Na}^{+}\right]$falls below $120 \mathrm{mEq} / \mathrm{L}$ and especially if the disorder has developed rapidly, stupor, seizures, brain stem herniation and coma may occur. ${ }^{10-13}$ Solutes leave the brain tissue within hours, thereby inducing water loss and reducing brain swelling. ${ }^{13}$ This adaptive mechanism accounts for the relatively asymptomatic nature of even severe hyponatremia if it develops slowly. ${ }^{10-14}$

\section{Pathophysiology}

Hyponatremia is defined as a decreased serum $\left[\mathrm{Na}^{+}\right]$ concentration (traditionally $\leq 135 \mathrm{mEq} / \mathrm{L}$ ). Accordingly, hyponatremia reflects a disturbance in water rather than $\left[\mathrm{Na}^{+}\right]$balance, although several interactions between the two regulatory systems exist. The definition of hyponatremia is based on concentration; therefore it does not provide information on extracellular fluid volume (ECF) in which $\left[\mathrm{Na}^{+}\right]$is measured. As a result, hyponatremia can occur in the context of contracted ECF (hypovolemia), normal ECF (euovolemia) or expanded ECF (hypervolemia). ${ }^{10}$

Many conditions can lead to hyponatremia, which can be associated with low, normal or high osmolality. ${ }^{14}$ Hypo-osmolar hyponatremia is by far the most common form of this disorder, ${ }^{10}$ and is caused by multiple medical conditions (Table 1). Hyponatremia can be associated with normal plasma osmolality in cases of extreme hyperlipidemia or hyperproteinemia (pseudohyponatremia) or high osmolality in hyperglycemia and with mannitol use, secondary to a shift of water from the cells to the extracellular compartment. ${ }^{10,15,16}$

\section{Arginine vasopressin}

Water balance regulation is primarily designed to control serum osmolality and to a lesser extent blood volume, ${ }^{17}$ and the
Table I Causes of hyponatremia

I. Hyponatremia with normal plasma osmolality (pseudohyponatremia)
I. Hyperlipidemia
2. Hyperproteinemia
II. Hyponatremia with increased plasma osmolality
I. Hyperglycemia
2. Mannitol use
3. Radiographic contrast agents
III. Hypo-osmolar (hypotonic) hyponatremia
A. Euvolemic
I. Syndrome of inappropriate antidiuretic hormone secretion
2. Hypothyroidism
3. Glucocorticoid deficiency
4. Strenuous exercise
5. Primary polydipsia
6. Decreased solute intake
B. Hypervolemic
I. Heart failure
2. Cirrhosis
3. Nephrotic syndrome
4. Pregnancy

central role of AVP in the pathogenesis of hyponatremia was recognized more than half a century ago. ${ }^{18,19}$

AVP is synthesized primarily in the magnocellular neurons of the hypothalamic paraventricular nuclei and in the supraoptic nuclei that project to the posterior pituitary. ${ }^{20}$ In addition, parvocellular neurons of the paraventricular nuclei co-expressing AVP and corticotropin-releasing hormone $(\mathrm{CRH})$ coordinate hypothalamic-pituitary-adrenal (HPA) system activity and project to the external layer of the median eminence, where AVP and CRH are released into the hypophyseal portal blood. ${ }^{21}$ The AVP precursor protein contains sequences for 3 separate peptides which split during transport down the nerve axon to the posterior pituitary into AVP, neurophysin and a glycopeptide.

AVP is regulated by 3 mechanisms: osmoreceptors, barorecepors and the rennin-angiotensin aldosterone system (RAAS).

Under normal conditions, the release of AVP is primarily controlled by the osmoreceptors. ${ }^{22}$ The serum osmolality is sensed by osmoreceptors in several parts of the brain, including the supraoptic nuclei of the hypothalamus, the subfornical organ, and the organum vasculosum of the lamina terminalis. ${ }^{22,23}$ Osmolality is regulated by thirst and renal responsiveness to AVP in addition to AVP release. ${ }^{23}$ Alterations of the plasma osmolality are detected by 
the osmoreceptors in the vicinity of the supraoptic and paraventricular areas of the anterior hypothalamus, which are supplied by blood from the internal carotid. A rise in serum osmolality causes water to move through the water channels of the osmoreceptor cell membranes, which then causes a change in cell volume that leads to an increase in the activity of stretch-inhibited cation channels. ${ }^{21}$ The accelerated action potential discharge causes an influx of calcium through a voltage-gated calcium channel which triggers a cascade of molecular events that ultimately leads to the neurosecretion of secretory vesicles containing AVP into the bloodstream. ${ }^{21,22}$

AVP starts to rise after $1 \%$ increase in serum osmolality or $5 \%$ to $10 \%$ decrease in blood volume. ${ }^{17}$ The second mechanism regulating AVP release is mediated by baroreceptors located in the carotid sinus and stretch receptors in the walls of the great veins, atria and pulmonary trunk. These receptors are sensitive to changes in circulating blood volume triggered by hypotension and/or volume depletion. In conditions characterized by arterial underfilling such as low cardiac output or decreased systemic vascular resistance the baroreceptors generate afferent signals to the vasomotor center. This results in activation of efferent pathways in the sympathetic nervous system (SNS) leading to increase in the rate of AVP secretion by the cells in the paraventricular and supraoptic nuclei. ${ }^{24}$

The third mechanism is related to actions of the RAAS, ${ }^{25,26}$ in which angiotensin II directly stimulates the secretion of AVP.

In the majority of patients, hyponatremia develops because AVP is secreted nonosmotically, resulting in renal water reabsorption. The four mechanisms that can cause inappropriate AVP effects ${ }^{27}$ include: (1) nonosmotic AVP release by the posterior pituitary induced by specific stimuli to the paraventricular or supraoptic nuclei; ${ }^{24}$ (2) ectopic AVP production; ${ }^{28}$ (3) factors that may enhance the renal effects of AVP, ${ }^{29}$ and (4) an AVP-like effect caused by an activating mutation of the vasopressin-2 receptor. ${ }^{27,30}$

The neurohypophysial antidiuretic hormone AVP regulates free water reabsorption, body fluid osmolality, blood volume, blood pressure, cell contraction, cell proliferation and adrenocorticotropic hormone (ACTH) secretion via the stimulation of specific G-protein-coupled receptors currently classified into $\mathrm{V}_{1}$-vascular receptor $\left(\mathrm{V}_{1 \mathrm{~A}}\right), \mathrm{V}_{2}$-renal receptor $\left(\mathrm{V}_{2}\right)$ and $\mathrm{V}_{3}$-pituitary receptor $\left(\mathrm{V}_{1 \mathrm{~B}}\right)$ subtypes. ${ }^{31,32}$

\section{Vasopressin receptors}

The $\mathrm{V}_{1 \mathrm{~A}}$ receptors are found mainly on vascular smooth muscle cells but also in many tissues, including brain, pituitary, hepatic, uterus, renal, adrenal, and platelets, ${ }^{31,32}$ while the $\mathrm{V}_{1 \mathrm{~B}}$, distinguished from the $\mathrm{V}_{1 \mathrm{~A}}$ subtype by different agonist and antagonist affinities, are expressed in cells of the anterior pituitary and throughout the brain, especially in the pyramidal neurons of the hippocampus and in the pancreas. ${ }^{33,34}$ The renal receptors $\left(\mathrm{V}_{2}\right)$ are located on the principal cells of the collecting ducts of kidney and in vascular smooth muscle and endothelial cells. ${ }^{31,32}$

Stimulation of the $\mathrm{V}_{1 \mathrm{~A}}$ receptor results in vasoconstriction, glycogenolysis, platelet aggregation, myocyte hypertrophy, anxiety and stress. ${ }^{31,32}$ While stimulation of the $\mathrm{V}_{1 \mathrm{~B}}$ receptor results in the release of $\mathrm{ACTH} .^{35,36}$

Stimulation of the $\mathrm{V}_{2}$ receptor results in vasodilatation, release of von Willebrand factor and factor 8 as well as water retention..$^{31,35}$ The effect of AVP on vascular contractility is dosedependent. At low concentrations, it causes vasoconstriction and, at higher concentrations, it causes vasodilatation. ${ }^{37}$

AVP exerts its actions through binding to typical heptahelical transmembrane G-protein-coupled receptors with distinct second messenger systems; stimulation of the $\mathrm{V}_{1 \mathrm{~A}}$ and $\mathrm{V}_{1 \mathrm{~B}}$ receptors ultimately results in a considerable increase in the cytosolic free calcium as a secondary messenger via phosphatidylinosilol hydrolysis and 1,2 diacylglycerol signaling pathway. The calcium signal may express its activity through a number of binding proteins including calmodulin, gelsolin or villin, troponin $\mathrm{C}$ or protein kinase $\mathrm{C} .^{28}$

Stimulation of the $V_{2}$ receptor on the other hand leads to the activation of adenylyl cyclase, resulting in an increase of intracellular c-AMP, and protein kinase A (PKA), which triggers phosphorylation of many proteins including aquaporin 2 (AQP-2). ${ }^{31} \mathrm{c}$-AMP then causes fusion of AQP-2 containing intracytoplasmic vesicles with the apical plasma membrane of the principal cell, leading to increased permeability and thus enhanced water reabsorption. ${ }^{28,31,37}$

The presence of AQPs in combination with an osmotic gradient allows water to move through the baso-lateral plasma membrane of the principal cell, returning to the bloodstream via the constitutively expressed AQP3 and AQP4 water channels. ${ }^{29,38} \mathrm{AVP}$ also increases $\left[\mathrm{Na}^{+}\right]$and urea permeability in the collecting duct (by increasing the number of the epithelial $\left[\mathrm{Na}^{+}\right]$channel, $\mathrm{ENaC}$, and the urea transporter, UT-A1), thereby maintaining the osmotic and medullary interstitial gradients and further stimulating antidiuresis. ${ }^{38}$

\section{Vasopressin receptors antagonists (VRAs)}

AVP receptors antagonists were first developed as peptide antagonists in the 1960s. These compounds had the 
disadvantages of having poor oral bioavailability and short half-lives. ${ }^{39}$ The first nonpeptide $\mathrm{V}_{2}$ antagonist was characterized in Japan by Yamamura et al in $1991 .^{40}$ The nonpeptide VRAs were more bioavailable, with longer halflives, than the earlier peptide formulations. ${ }^{39}$

Several nonpeptide VRAs have been studied, and were developed as oral or intravenous (iv) formulations. They differ in their relative selectivity for the various AVP receptor subtypes $^{31}$ and include tolvaptan (oral, selective $V_{2}$ VRA) that was recently approved by the United States Food and Drug Administration (FDA) for the treatment of symptomatic or severe hyponatremia (serum $\left[\mathrm{Na}^{+}\right]<125 \mathrm{mEq} / \mathrm{L}$ ); lixivaptan (oral, selective $\mathrm{V}_{2}$ VRA) which is currently under intense investigation for its potential role in the treatment of hyponatremia in heart failure; and conivaptan, the first approved nonpeptide $\mathrm{V}_{1 \mathrm{~A}} / \mathrm{V}_{2}$ VRA that will be discussed in more details.

It would be useful, however, to first briefly review the reasons for the search for more effective modality for the treatment of hyponatremia.

\section{Limitations of current treatments for hyponatremia}

There are many limitations to the use of traditional treatment of hyoponatremia. ${ }^{41,42}$ The infusion of hypertonic saline, increasing serum $\left[\mathrm{Na}^{+}\right]$by 2 to $4 \mathrm{mEq} / \mathrm{L}$ within 2 to 4 hours is associated with significant fluid overload and many clinicians are uncomfortable using it in patients with volume overload. Fluid restriction plays a cornerstone role in the treatment of hyponatremia but it is fraught with problem of compliance. Lithium has also been used to induce nephrogenic diabetes insipidus, but it has many side effects including renal impairment, central nervous system effects and thyroid dysfunction. The response is erratic and frequent monitoring is needed to ensure that blood levels remain within the therapeutic range. Demeclocycline is another treatment option, but it has many drawbacks including variable response to treatment, poor gastrointestinal tolerance, photosensitivity and renal and hepatic toxic effects. Urea has been used in patients with severe symptoms as it promotes rapid reduction of brain edema without the risk of salt overload that accompany hypertonic saline, however, it is not well tolerated due to poor palatability and the need for concomitant fluid restriction to achieve good results. Finally, diuretics often do not correct hypotonic hyponatremia, they may actually contribute to hyponatremia by promoting excretion of $\left[\mathrm{Na}^{+}\right]$and decreasing the excretion of electrolyte-free water. In addition, the effectiveness of diuretics is related to the amount of $\left[\mathrm{Na}^{+}\right]$ reaching the loop of Henle and diminished $\left[\mathrm{Na}^{+}\right]$delivery in advanced heart failure results in diminished diuresis.

\section{Conivaptan (YM087)}

Conivaptan hydrochloride is a nonpeptide, benzazepine derivative and the only dual $\mathrm{V}_{1 \mathrm{~A}}$ and $\mathrm{V}_{2}$ AVP receptor antagonist. It has almost no effect on $\mathrm{V}_{1 \mathrm{~B}}$ receptors. In vitro animal studies have shown that the drug has high affinity for both $\mathrm{V}_{1 \mathrm{~A}}$ and $\mathrm{V}_{2}{ }^{44}$ The antagonistic effect of conivaptan is concentration dependent and it binds competitively with an affinity 10 -fold higher for $\mathrm{V}_{2}$ than for $\mathrm{V}_{1 \mathrm{~A}}$ recptors ${ }^{45}$ and binds reversibly to both receptors.

Conivaptan was discovered first in Japan by Yamanouchi Pharmaceutical Co. Ltd., and further developed in the United States, by Astellas Pharma US Inc. ${ }^{43}$

It is the first AVP receptors antagonist to be approved by FDA for the use in the management of refractory euvolemic and hypervolemic hyponatremia, as intravenous infusion in the inpatient setting.

\section{Pharmacokinetics}

The pharmacokinetics of conivaptan has been studied using both oral and iv formulations in animals and humans (Table 2). In a study in the rat, oral formulation effect was dose dependant and persisted for more than 24 hours showing possibilities of long duration of action. ${ }^{44,45}$ In humans, oral conivaptan, at a dose of $60 \mathrm{mg}$, showed $44 \%$ bioavailability and short half-life in 6 healthy individuals, and its pharmacodynamic effects persisted for at least 6 hours. ${ }^{46}$

In a study among healthy male subjects, conivaptan was administered as $20 \mathrm{mg}$ loading dose (infused over 30 minutes) followed by continuous infusion of $40 \mathrm{mg} /$ day for 3 days. Mean $\mathrm{C}_{\max }$ for conivaptan was $619 \mathrm{ng} / \mathrm{mL}$ and occurred at the end of the loading dose, plasma concentration reached a minimum at approximately 12 hours after the start of the loading dose, and then gradually increased over the duration of the infusion to a mean concentration of $188 \mathrm{ng} / \mathrm{mL}$ at the end of the infusion. The mean terminal elimination halflife after conivaptan infusion was 5.0 hours, and the mean clearance was 15.2 L/hour. $^{47}$

\section{Drug formulation and dosing}

Conivaptan hydrochloride is a white to off-white or pale orange-white powder that is very slightly soluble in water $\left(0.15 \mathrm{mg} / \mathrm{mL}\right.$ at $\left.23{ }^{\circ} \mathrm{C}\right)$. Conivaptan injection is supplied as a sterile liquid in an ampule. Each ampule delivers $20 \mathrm{mg}$ conivaptan hydrochloride, $1.2 \mathrm{~g}$ propylene glycol, $0.4 \mathrm{~g}$ ethanol, and water for injection. Lactic acid is added 
Table 2 Pharmacokinetics of conivaptan

\begin{tabular}{|c|c|}
\hline Parameter & Drug \\
\hline \multirow{3}{*}{$\overline{C_{\max }(\text { at } 0.5 \mathrm{~h})}$} & $619 \mathrm{ng} / \mathrm{mL}$ - median, healthy males ( $20 \mathrm{mg}$ loading dose $/ 20 \mathrm{mg} /$ day) \\
\hline & 575.8 ( 144.5 to 764.3$) \mathrm{ng} / \mathrm{mL}$ - median, hyponatremic patients ( $20 \mathrm{mg}$ loading dose $/ 20 \mathrm{mg} /$ day) \\
\hline & 78I.I (194.5 to I 373.5$) \mathrm{ng} / \mathrm{mL}$ - median, hyponatremic patients ( $20 \mathrm{mg}$ loading dose/40 mg/day) \\
\hline $\mathrm{T}_{\max }$ & 30 min (end of iv loading dose) \\
\hline$V_{d}$ & $32 \mathrm{~L}$ \\
\hline$t_{1 / 2}$ & Variable (secondary to nonlinear kinetics) \\
\hline Protein binding & $99 \%$ \\
\hline Metabolism & CYP3A4 (substrate and potent inhibitor); 4 active metabolites identified with minimal clinical effect \\
\hline \multirow[t]{3}{*}{ Elimination } & Eliminated primarily as metabolites ( $<1 \%$ recovered intact drug in urine) \\
\hline & $83 \%$ feces \\
\hline & $12 \%$ urine \\
\hline Mean clearance & $15.2 \mathrm{~L} / \mathrm{h}$ \\
\hline Bioavailability & $44 \%$ absorption with oral conivaptan formulation \\
\hline
\end{tabular}

for $\mathrm{pH}$ adjustment to $3.0 .^{47} \mathrm{~A}$ loading dose of $20 \mathrm{mg}$ is administered through a large vein given over $30 \mathrm{~min}$ followed by a maintenance dose of 20 to $40 \mathrm{mg} /$ day for up to 4 days by continuous infusion. It is recommended to change the infusion site every 24 hours to avoid infusion site complications. Close monitoring of serum $\left[\mathrm{Na}^{+}\right]$and volume status is recommended so the dose can be adjusted accordingly.

\section{Metabolism}

Conivaptan is $99 \%$ bound to human plasma protein at concentration range of 10 to $1000 \mathrm{ng} / \mathrm{mL}$. It is metabolized only by the liver cytochrome P450 isozyme (CYP3A4). The pharmacokinetics of oral and iv conivaptan are nonlinear. Four metabolites have been identified, and inhibition by conivaptan of its own metabolism seems to be the major factor for the nonlinearity. ${ }^{47}$ The pharmacological activity of the metabolites at $\mathrm{V}_{1 \mathrm{~A}}$ and $\mathrm{V}_{2}$ receptors ranged from approximately $3 \%$ to $50 \%$ and $50 \%$ to $100 \%$ that of conivaptan, respectively. After $10 \mathrm{mg}$ iv or $20 \mathrm{mg}$ oral dose, approximately $83 \%$ is excreted in feces, and $12 \%$ in urine. Approximately $1 \%$ of the iv dose is excreted as intact conivaptan in urine within 24 hours. ${ }^{47}$ Studies in special populations, including patients with renal and hepatic insufficiency, demonstrated higher levels of conivaptan after oral intake. Since iv conivaptan results in higher exposure to the drug, caution should be used in patients with hepatic or renal impairment. ${ }^{47}$

\section{Drug interaction}

Conivaptan is a sensitive substrate as well as a potent inhibitor of CYP3A4. ${ }^{43}$ Concomitant use of conivaptan with other drugs metabolized by CYP3A4 could result in a significant drug interaction, either by an increase in conivaptan levels, or an increase other drug levels and potentially their side effects. ${ }^{43}$ By decreasing clearance via CYP3A4, conivaptan can increase the risk of toxicity of certain drugs such as midazolam, simvastatin and amlodipine. For example, $30 \mathrm{mg} /$ day of iv conivaptan resulted in a 3-fold increase in the area under the curve (AUC) of simvastatin and was associated with an increased incidence of rhabdomyolysis. ${ }^{47}$ It also decreased the systemic clearance of digoxin by approximately $30 \%$ and thus increased its $\mathrm{AUC}$ and $\mathrm{C}_{\max }$ values potentiating digoxin toxicity. The pharmacokinetics of conivaptan was unchanged with co-administration of either captopril or furosemide. There was no observed effect of oral conivaptan on the pharmacokinetics or pharmacodynamics of warfarin. ${ }^{47}$ The effect of ketoconazole, a potent CYP3A4 inhibitor, on the serum levels of iv conivaptan has not been evaluated; however, co-administration of $10 \mathrm{mg}$ oral conivaptan with $200 \mathrm{mg}$ of ketoconazole resulted in a 4- and 11-fold increase in $\mathrm{C}_{\max }$ and $\mathrm{AUC}$ of conivaptan, respectively. Co-administration of clarithromycin (a strong CYP3A4 inhibitor) and conivaptan can increase the exposure to conivaptan and potentiate its toxicity ${ }^{47}$ (Table 3 ).

\section{Precautions, contraindications, side effects}

Serum $\left[\mathrm{Na}^{+}\right]$level should be strictly monitored during treatment to avoid overly rapid increase of serum $\left[\mathrm{Na}^{+}\right]$and the possible serious permanent neurological complications. Conivaptan should be used with caution in patients with renal or liver impairment since it can be associated with increased systemic exposure and potential side effects.

In pregnant rats and rabbits, conivaptan administration has shown a delay in fetal growth, physical development and sexual maturation. ${ }^{43,47}$ Therefore its use in pregnancy is classified as category $\mathrm{C}$ and should be used only if the potential 
Table 3 Medications with potential for significant drug interactions

\begin{tabular}{lll}
\hline Chemotherapeutic agents & Calcium channel blockers & Others \\
\hline Doxorubicin & Amlodipine & Quinidine \\
Etoposide (BP-16) & Diltiazem & Buspirone \\
Tamoxifen & Felodipine & Zolpidem \\
Vinblastine & Isradipine & Nefazodone \\
Vincristine & Lercanidipine & Trazodone \\
& Nicardipine & Carbamazepine \\
& Nifedipine & Glucocorticoids \\
& Nimodipine & Rifabutin \\
& Nisoldipine & \\
HMG CoA reductase inhibitors & Nitrendipine & \\
Atorvastatin $>60$ mg/day & Verapamil & Macrolide antibiotics \\
Lovastatin & Benzodiazipines & (except azithromycin, \\
Simvastatin & Alprazolam & dirithromycin and roxithromycin) \\
Rosuvastatin & Diazepam & \\
Protease inhibitors & Midazolam & \\
Ritonavir & Triazolam & Azole antifungals (except fluconazole and \\
Indinavir & Immunosuppressants & topical antifungals)
\end{tabular}

benefit justifies the potential risk to the fetus. Conivaptan is also contraindicated in lactation as it has been found in the milk of lactating animals. ${ }^{47}$

Conivaptan is contraindicated in hypernatremia, hypovolemic hyponatremia, and in those who have hypersensitivity to any of its components. Co-administration of conivaptan with potent CYP3A4 inhibitors such as ketoconazole, itraconazole, clarithromycin, ritonavir and indinavir is also contraindicated. ${ }^{47}$ In patients with hypovolemia or total body fluid depletion, conivaptan can potentially precipitate renal failure, ischemic organ damage, and shock and thus it is contraindicated. ${ }^{47}$

Conivaptan administration is usually well tolerated. The most common adverse reaction reported with conivaptan administration was infusion site reaction (including pain, erythema, phlebitis and swelling). This occurred in 52.5\% of subjects treated with conivaptan $40 \mathrm{mg}$ /day compared to $3.3 \%$ in the placebo group, in studies involving patients and healthy volunteers, and it was the most common reason for discontinuation of treatment. A pilot study done among patients hospitalized with acute decompenstated heart failure showed that infusion site reaction was the most reported side effect, and conivipatan was well tolerable among this patient population. ${ }^{48}$ Other reported side effects in decreasing order included orthostatic hypotension, fever, hypokalemia, hypertension, hypotension, peripheral edema, headache, hypomagnesaemia, constipation, diarrhea, nausea, vomiting, dry mouth, thirst, polyuria, oral candidiasis, pneumonia, urinary tract infection, insomnia and confusion. Conivaptan can also potentially precipitate renal failure, ischemic organ damage and shock. Common adverse reactions in 72 healthy volunteers and 243 patients with euvolemic and hypervolemic hyponatremia who received $20 \mathrm{mg}$ iv conivaptan loading dose followed by $40 \mathrm{mg} /$ day iv for 2 to 4 days were reported as follows: infusion site phlebitis (32\%), infusion site reaction (19\%), hypokalemia and headache $(10 \%)$, peripheral edema $(8 \%)$, vomiting and diarrhea (7\%), anemia, constipation, infusion site erythema, thirst, hyponatremia, hypertension, and orthostatic hypotension $(6 \%){ }^{49}$

\section{The risk of rapid correction of hyponatremia}

Prompt and adequate treatment of hyponatremia is necessary to relieve early symptoms and prevent progression to seizures and irreversible brain damage. However rapid correction of hyponatremia may cause osmotic demyelinating syndrome (ODS), leading to permanent disability or death. In chronic hyponatremia, brain cells lose osmolytes, leading to movement of water out of the cells, a mechanism that offers protection from developing cerebral edema. ${ }^{50,51}$ These osmolytes include $\left[\mathrm{Na}^{+}\right]$, potassium and 
organic solutes. Activation of cation channels leads to rapid movement of electrolytes whereas organic solute loss occurs later because it requires the synthesis of new transporters. ${ }^{52-54}$ How ODS develops is not completely understood, however, the mechanism appears to be that osmolytes cannot be quickly replaced as the brain volume shrinks in response to an elevation in the plasma $\left[\mathrm{Na}^{+}\right]$ concentration..$^{55}$ As a result, it is currently recommended that the plasma $\left[\mathrm{Na}^{+}\right]$concentration in hyponatremic patients be elevated at a maximum rate of 10 to $12 \mathrm{mEq} / \mathrm{L}$ during the first day and $18 \mathrm{mEq} / \mathrm{L}$ over the first 2 days. ${ }^{41,42}$

Rapid serum $\left[\mathrm{Na}^{+}\right]$correction was defined in conivaptan clinical trials by the occurrence of any of the following 1) An increase in serum $\left[\mathrm{Na}^{+}\right]>12 \mathrm{mEq} / \mathrm{L}$ in 1 day; 2) a total increase in serum $\left[\mathrm{Na}^{+}\right]$of more than $24 \mathrm{mEq} / \mathrm{L} ; 3$ ) serum $\left[\mathrm{Na}^{+}\right]>145 \mathrm{mEq} / \mathrm{L}$; or 4 ) reduced or temporarily withheld treatment after an increase in serum $\left[\mathrm{Na}^{+}\right]$judged to be too rapid. The reported prevalence of rapid correction in conivaptan clinical trials is $9 \%$ with no occurrence of permanent neurologic sequela. However, this prevalence was based mainly on one criterion, an increase of serum $\left[\mathrm{Na}^{+}\right]>12 \mathrm{mEq} / \mathrm{L}$ in 24 hours and the prevalence may be somewhat higher if all above mentioned definitions were used. To date there has been no report of ODS with the use of conivaptan or any other VRAs.

\section{Conivaptan in the treatment of hyponatremia}

\section{Animal studies}

Antagonism of the $\mathrm{V}_{2}$ receptor increases free water excretion causing hypo-osmolar urine, enhanced diuresis, and increased plasma $\left[\mathrm{Na}^{+}\right]$levels. Several animal studies have demonstrated the aquaretic effect of conivaptan (Table 4). Yatsu et $\mathrm{a}^{56}$ showed in conscious dogs that the administration of both oral and iv conivaptan resulted in a dose-dependent aquaresis. Tomura et $\mathrm{al}^{57}$ showed that oral conivaptan increased the urine volume and reduced the urine osmolality in dehydrated conscious rats and compared to furosemide the amount in $\left[\mathrm{Na}^{+}\right]$excretion was much lower. In a study in normal conscious rats by Risvanis et al, ${ }^{44}$ oral conivaptan caused a dose dependent increase in urine volume and fluid intake and decreased urine osmolality without natriuresis. Tahara et $\mathrm{al}^{45}$ showed that iv administration of conivaptan increased urine volume and reduced urine osmolality in a dose dependent manner in dehydrated rats and Wada et $\mathrm{al}^{58}$ showed that iv conivaptan produced statistically significant

Table 4 Effect of conivaptan on urinary volume and $\left[\mathrm{Na}^{+}\right]$concentration in animals

\begin{tabular}{|c|c|c|c|c|}
\hline References & Species & $\begin{array}{l}\text { Condition } \\
\text { of species }\end{array}$ & Intervention & Results \\
\hline Risvanis et $\mathrm{al}^{44}$ & $\begin{array}{l}\text { Rats } \\
\text { (male Sprague-Dawley) }\end{array}$ & $\begin{array}{l}\text { Normal } \\
\text { Conscious }\end{array}$ & $\begin{array}{l}\text { Vehicle or } 1 \mathrm{mg} / \mathrm{kg} \text { iv or } 3 \mathrm{mg} / \mathrm{kg} \\
\text { oral conivaptan }\end{array}$ & $\begin{array}{l}\text { Dose-dependent increase in urine volume } \\
\text { and decrease in urine osmolality without } \\
\text { natriuresis }\end{array}$ \\
\hline Tahara et $\mathrm{al}^{45}$ & $\begin{array}{l}\text { Rats } \\
\text { (male and female Wistar) }\end{array}$ & $\begin{array}{l}\text { Dehydrated } \\
\text { Conscious }\end{array}$ & $\begin{array}{l}\text { Vehicle or } 0.01 \text { to } 0.3 \mathrm{mg} / \mathrm{kg} \text { iv } \\
\text { conivaptan }\end{array}$ & $\begin{array}{l}\text { Increased urine volume and reduced urine } \\
\text { osmolality in a dose-dependent manner }\end{array}$ \\
\hline Yatsu et $\mathrm{al}^{56}$ & $\begin{array}{l}\text { Dogs } \\
\text { (female Beagle) }\end{array}$ & $\begin{array}{l}\text { Normal } \\
\text { Conscious }\end{array}$ & $\begin{array}{l}\text { Oral } 0.03 \text { to } 0.3 \mathrm{mg} / \mathrm{kg} \text { or } 0.0 \mathrm{I} \\
\text { to } 0.1 \mathrm{mg} / \mathrm{kg} \text { iv conivaptan or iv } \\
\text { furosemide } 0.3 \mathrm{mg} / \mathrm{kg}\end{array}$ & Dose-dependent aquaresis \\
\hline Tomura et $\mathrm{a}^{57}$ & $\begin{array}{l}\text { Rats } \\
\text { (male Wistar) }\end{array}$ & $\begin{array}{l}\text { Normal and } \\
\text { dehydrated } \\
\text { Conscious }\end{array}$ & $\begin{array}{l}\text { I-dehydrated: } 0.1,0.3,1,3 \mathrm{mg} / \mathrm{kg} \text { oral } \\
\text { conivaptan or furosemide } 3,10,30 \text {, } \\
100 \mathrm{mg} / \mathrm{kg} \\
\text { 2-hydrated: vehicle or } 0.3,1,3 \mathrm{mg} / \mathrm{kg} \\
\text { oral conivaptan or furosemide } \\
100 \mathrm{mg} / \mathrm{kg}\end{array}$ & $\begin{array}{l}\text { (I) Dose-dependent increase in urine } \\
\text { volume and reduction in urine osmolarity. } \\
\text { Increased urinary }\left[\mathrm{Na}^{+}\right] \text {excretion to a } \\
\text { lower degree than furosemide } \\
\text { (2) Dose-dependent increase in urine } \\
\text { volume with longer duration of diuresis } \\
\text { compared to furosemide }\end{array}$ \\
\hline Wada et $\mathrm{a}^{58}$ & $\begin{array}{l}\text { Rats }(n=44) \\
\text { (male Wistar) }\end{array}$ & $\begin{array}{l}\text { SIADH } \\
\text { Conscious }\end{array}$ & $\begin{array}{l}\text { Vehicle or } 0.1,1 \mathrm{mg} / \mathrm{kg} \text { iv conivaptan } \\
\text { vs } \\
\text { Vehicle or furosemide } 10 \mathrm{mg} / \mathrm{kg}\end{array}$ & $\begin{array}{l}\text { Increased both blood }\left[\mathrm{Na}^{+}\right] \text {concentration } \\
\text { and plasma osmolality vs no effect of } \\
\text { furosemide on either } \\
\text { IV furosemide did not increase either blood } \\
{\left[\mathrm{Na}^{+}\right] \text {concentration or plasma osmolality }}\end{array}$ \\
\hline
\end{tabular}

Abbreviations: iv, intravenous; SIADH, syndrome of inappropriate secretion of antidiuretic hormone. 
increase in blood $\left[\mathrm{Na}^{+}\right]$concentration and plasma osmolality in rats with SIADH.

\section{Human studies}

The effects of conivaptan on serum $\left[\mathrm{Na}^{+}\right]$in patients with euvolemic and hypervolemic hyponatremia have been studied in 3 randomized, double-blinded, placebo-controlled clinical trials (two with oral and one with iv conivaptan) and in one open label iv study (Table 5).

In a study by Ghali et al, ${ }^{59} 74$ patients with euvolemic or hypervolemic hyponatremia as defined by serum $\left[\mathrm{Na}^{+}\right]$of 115 to $<130 \mathrm{mEq} / \mathrm{L}$ were stratified by volume status and assigned randomly in 1:1:1 ratio to receive oral placebo, $40 \mathrm{mg} /$ day or $80 \mathrm{mg} /$ day conivaptan in 2 divided doses. Euvolemic hyponatremia was present in $75 \%$ of patients. The primary efficacy end point was the change from baseline in serum $\left[\mathrm{Na}^{+}\right]$throughout the 5 days of treatment, as measured by the serum $\left[\mathrm{Na}^{+}\right]$ AUC. The conivaptan groups, 40 and $80 \mathrm{mg} /$ day had least square (LS) mean change from baseline in serum $\left[\mathrm{Na}^{+}\right]$AUC during the 5-day treatment that was 2-fold $(P=0.03)$ and 2.5 -fold $(P<0.001)$ greater, respectively, than placebo. Also, the efficacy on secondary end points was consistent including shorter median time to achieve a confirmed increase in serum $\left[\mathrm{Na}^{+}\right]$of $4 \mathrm{mEq} / \mathrm{L}$ or more from baseline $(P<0.044$ for the $40 \mathrm{mg} /$ day and $P<0.002$ for the $80 \mathrm{mg} /$ day conivaptan), a longer mean total times during which patients had a serum $\left[\mathrm{Na}^{+}\right]$level of $4 \mathrm{mEq} / \mathrm{L}$ or more above baseline $(P<0.001)$, a greater LS mean change in serum $\left[\mathrm{Na}^{+}\right]$from baseline to end of treatment $(P<0.002)$ and a higher percentage of a confirmed normal serum $\left[\mathrm{Na}^{+}\right] \geq 135 \mathrm{mEq} / \mathrm{L}$ or increase of $6 \mathrm{mEq} / \mathrm{L}$ or more $(P<0.014)$.

In the recently published multicenter European study by Annane et a ${ }^{60} 83$ patients with euvolemic or hypervolemic hyponatremia with serum $\left[\mathrm{Na}^{+}\right]$ $<130 \mathrm{mEq} / \mathrm{L}$, plasma osmolarity $<290 \mathrm{mOsmol} / \mathrm{kg} \mathrm{H}_{2} \mathrm{O}$ and no evidence of extracellular volume depletion were divided into three different groups and received conivaptan $20 \mathrm{mg}$ twice daily (40 mg/day), conivaptan $40 \mathrm{mg}$ twice daily ( $80 \mathrm{mg} /$ day), or placebo for 5 days as inpatients. All patients were prescribed fluid restriction and diuretic doses were stabilized before screening and remained constant throughout the study. Euvolemic hyponatremia was present in $63 \%$ at baseline, and the most common single causes of hyponatremia were heart failure $(33 \%)$ and cancer $(17 \%)$. The primary efficacy end point was the change from baseline in serum $\left[\mathrm{Na}^{+}\right]$ throughout the 5 days of treatment, as measured by the serum $\left[\mathrm{Na}^{+}\right]$AUC. Conivaptan produced a dose-dependent and significantly greater increase in serum $\left[\mathrm{Na}^{+}\right] \mathrm{AUC}$ than placebo $(P<0.0001)$. The difference in serum $\left[\mathrm{Na}^{+}\right]$ AUC between the 2 conivaptan doses was also statistically significant $(P<0.028)$.

The efficacy on secondary endpoints was also consistent. Both doses of conivaptan achieved shorter median times from the first dose to a confirmed serum $\left[\mathrm{Na}^{+}\right]$increase of $4 \mathrm{mEq} / \mathrm{L}$ or greater from baseline $(P<0.0004$ for the $40 \mathrm{mg} /$ day and $P<0.0001$ for the conivaptan $80 \mathrm{mg} /$ day). Both groups were significantly different from the placebo group. The median time was not estimable in the placebo group (too few patients achieved an increase of $4 \mathrm{mEq} / \mathrm{L}$ or greater during the 5-day study). Moreover, the LS mean total time during which patients had an increase in serum $\left[\mathrm{Na}^{+}\right]$of $4 \mathrm{mEq} / \mathrm{L}$ or more from baseline was significantly greater among patients given conivaptan $40 \mathrm{mg} /$ day and $80 \mathrm{mg} /$ day compared to placebo $(P<0.0001)$.

Both doses of conivaptan had greater LS mean $\pm \mathrm{SE}$ change in serum $\left[\mathrm{Na}^{+}\right]$from baseline to the end of treatment $(P<0.0001)$. Similarly, both doses of conivaptan groups had a higher number of patients who demonstrated either a confirmed serum $\left[\mathrm{Na}^{+}\right]$of $6 \mathrm{mEq} / \mathrm{L}$ or more above baseline or normal serum $\left[\mathrm{Na}^{+}\right](\geq 135 \mathrm{mEq} / \mathrm{L})$ ( $P<0.0008$ for the $40 \mathrm{mg} /$ day vs $P<0.001$ for the conivap$\tan 80 \mathrm{mg} /$ day). Of note, 7 days after the study ended, both conivaptan groups had higher change in serum $\left[\mathrm{Na}^{+}\right]$than those in placebo group. Finally, conivaptan, in comparison with placebo, produced greater increases in free and effective water clearance, net fluid loss, plasma osmolality and greater reductions in urine osmolality and urine $\left[\mathrm{Na}^{+}\right]$levels.

Iv conivaptan has been shown to have similar effects on serum $\left[\mathrm{Na}^{+}\right]$. In a study by Zeltser et al, ${ }^{61} 84$ patients hospitalized with euvolemic and hypervolemic hyponatremia, with serum $\left[\mathrm{Na}^{+}\right]$of $115 \mathrm{mEq} / \mathrm{L}$ to $<130 \mathrm{mEq} / \mathrm{L}$ were randomized to receive placebo or $20 \mathrm{mg}$ of conivaptan as a bolus iv dose, followed by a continuous infusion of 40 or $80 \mathrm{mg}$ per day for 4 days. Both conivaptan doses increased $\left[\mathrm{Na}^{+}\right]$AUC during the 4 -day treatment $(P<0.0001$ vs placebo) and the LS mean changes in serum $\left[\mathrm{Na}^{+}\right]$at day 4 for the 3 respective groups were significanly greater with conivaptan $(P<0.001)$ and so was the percentage of patients achieving $6 \mathrm{mEq} / \mathrm{L}$ or more increase in serum $\left[\mathrm{Na}^{+}\right]$from baseline or normalization of $\left[\mathrm{Na}^{+}\right]$(defined as $\geq 135 \mathrm{mEq} / \mathrm{L})(P<0.001)$. The median time from the 
first dose to $4 \mathrm{mEq} / \mathrm{L}$ increase in serum $\left[\mathrm{Na}^{+}\right]$was 23.7 hours and 23.4 hours for the conivaptan $40 \mathrm{mg} /$ day and $80 \mathrm{mg} /$ day groups, respectively $(P<0.001)$.

In all of these randomized studies, the magnitude of changes in serum $\left[\mathrm{Na}^{+}\right]$was clinically significant. One might speculate that the design of these studies could have been benefited by separating the included patient population by the etiology of hyponatremia or by stratifying randomization by etiology (heart failure vs SIADH). In addition, detailed information on fluid input and output would have provided additional information. Finally, a serial measurement of serum $\left[\mathrm{Na}^{+}\right]$over extent period of time would have shed light on the duration of corrected hyponatremia and the frequency with which it persists.

Verbalis et al conducted an open-label trial ${ }^{62}$ investigating 4 days treatment with iv conivaptan The magnitude of changes in serum $\left[\mathrm{Na}^{+}\right]$sodium is clinically significant: $20 \mathrm{mg} /$ day $(\mathrm{n}=37)$ or $40 \mathrm{mg} /$ day $(\mathrm{n}=214)$ in patients with euvolemic or hypervolemic hyponatremia. Patients received a loading dose of iv conivaptan $20 \mathrm{mg}$ as a 30 -minute infusion followed by a continuous iv infusion of conivaptan 20 or $40 \mathrm{mg} /$ day for 4 days. The primary efficacy point was baseline adjusted serum $\left[\mathrm{Na}^{+}\right]$area under the curve over the duration of treatment, which was $753.8 \mathrm{mEq} \cdot \mathrm{h} / \mathrm{L}+429.9$ in the $20 \mathrm{mg}$ /day group and $689.2 \mathrm{mEq} \cdot \mathrm{h} / \mathrm{L}+417.3$ in the $40 \mathrm{mg} /$ day group.

Only iv conivaptan has been approved for use in hospitalized patients with euvolemic and hypervolemic hyponatremia. The development of the oral formulation was stopped because of multiple drug-drug interactions due to inhibition of CYP3A4 in intestine and liver that is involved in the metabolism of many drugs especially cardiovascular medications.

\section{Use of conivaptan in heart failure}

Heart failure is characterized by neurohormonal activation that plays a central role in $\left[\mathrm{Na}^{+}\right]$and water retention. Several mechanisms mediate volume overload and hyponatremia in heart failure, and both hyponatremia and congestion share many common pathophysiological pathways including activation of the SNS, the RAAS and AVP. ${ }^{24}$ Antagonism of the multiple actions mediated by AVP and the potential beneficial effect of conivaptan in heart failure has been investigated in several studies.

\section{Animal studies}

AVP has been shown, through the activation of $\mathrm{V}_{1 \mathrm{~A}}$ receptor, to increase the rate of protein synthesis in the myocardium leading to myocyte hypertrophy in rats ${ }^{63-66}$ (Table 6). In a study by Tahara et al, ${ }^{65}$ conivaptan was demonstrated to have dose-dependent inhibition of the AVP-induced protein synthesis in neonatal rat cardiomyoctes. Similar effects of conivaptan were demonstrated in another study by Tahara et $\mathrm{al}^{65}$ in rat vascular smooth muscles. ${ }^{66}$

The effects of conivaptan on the hemodynamics in heart failure have also been studied in multiple animal models (Table 6).

Conivaptan reversed the decrease in cardiac output and the increase in total peripheral resistance induced by AVP in dogs without heart failure.$^{67}$ In a dog model with pacing induced heart failure, iv conivaptan increased cardiac output and stroke volume, reduced preload and afterload, increased urine flow and decreased urine osmolarity. ${ }^{68}$

In rats with myocardial infarction induced heart failure, both oral and iv conivaptan increased myocardial contractility and reduced right atrial and both right and left ventricular end diastolic pressures compared to control. ${ }^{69}$ It also increased urine volume and reduced urine osmolarity in rats with and without coronary heart failure. ${ }^{70}$

\section{Human studies (Table 7)}

Several studies have been performed to assess the effects of conivaptan in heart failure (Table 7). A hemodynamic doubleblinded, randomized, placebo-controlled study of 142 patients with heart failure (NYHA class III and IV) receiving a single dose of iv conivaptan demonstrated a significant reduction in pulmonary capillary wedge pressures $(P<0.05)$ and right atrial pressure $(P<0.05)$ compared to placebo. The hemodynamic improvements were accompanied by increased urine output $(P<0.001)$ without affecting renal function. There were no significant changes in cardiac index, systemic and pulmonary vascular resistance, blood pressure and heart rate compared to placebo. ${ }^{71}$

The effects of conivaptan on heart failure symptoms and functional capacity were evaluated in a 12-week oral administration study, A Dose Evaluation of a Vasopressin Antagonist in CHF Patients undergoing Exercise (ADVANCE). ${ }^{72}$ Among 345 patients with class II-IV heart failure, randomized to oral conivaptan 10, 20, $40 \mathrm{mg}$ twice daily or placebo, there was no significant difference in exercise tolerance, as measured by the time to reach $70 \%$ of peak oxygen consumption, between conivaptan and placebo.

In recent double blinded, multicenter study, ${ }^{48}$ the use of conivaptan was evaluated in 170 patients admitted with acute decompensated heart failure with worsening dyspnea and pulmonary vascular congestion. The mean age was 
Table 5 Conivaptan studies in patients with hyponatremia

\begin{tabular}{|c|c|c|c|c|c|c|c|c|c|}
\hline Baseline $\mathbf{N a}^{+}$ & \multicolumn{3}{|c|}{ Ghali et al ${ }^{59}$} & \multicolumn{3}{|c|}{ Annane et $a^{160}$} & \multicolumn{3}{|c|}{ Zeltser et $\mathrm{al}^{|6|}$} \\
\hline $\begin{array}{l}\text { Total number } \\
\text { of patients }\end{array}$ & \multicolumn{3}{|l|}{74} & \multicolumn{3}{|l|}{83} & \multicolumn{3}{|l|}{84} \\
\hline Ethnicity & \multicolumn{3}{|c|}{$89 \%$ Whites } & \multicolumn{3}{|c|}{$100 \%$ Whites } & \multicolumn{3}{|c|}{ 85.7\% Whites } \\
\hline Females & \multicolumn{3}{|l|}{$51.4 \%$} & \multicolumn{3}{|l|}{$33.7 \%$} & \multicolumn{3}{|l|}{$51.2 \%$} \\
\hline Age $>65$ & \multicolumn{3}{|l|}{$68 \%$} & \multicolumn{3}{|l|}{$47 \%$} & \multicolumn{3}{|l|}{$71.4 \%$} \\
\hline Age & \multicolumn{3}{|l|}{ - } & \multicolumn{3}{|l|}{ - } & \multicolumn{3}{|l|}{-} \\
\hline Euvolemic \% & \multicolumn{3}{|l|}{$75 \%$} & \multicolumn{3}{|l|}{$62.7 \%$} & \multicolumn{3}{|l|}{$66.7 \%$} \\
\hline Design & \multicolumn{3}{|c|}{$\begin{array}{l}\text { Double-blinded, } \\
\text { placebo-controlled }\end{array}$} & \multicolumn{3}{|c|}{$\begin{array}{l}\text { Double-blinded, } \\
\text { placebo-controlled }\end{array}$} & \multicolumn{3}{|c|}{$\begin{array}{l}\text { Double-blinded, } \\
\text { placebo-controlled }\end{array}$} \\
\hline iv or oral conivaptan & \multicolumn{3}{|l|}{ Oral } & \multicolumn{3}{|l|}{ Oral } & \multicolumn{3}{|l|}{ iv } \\
\hline Dose of conivaptan & \multicolumn{3}{|c|}{$\begin{array}{l}\text { Placebo or conivaptan } \\
40 \text { or } 80 \mathrm{mg} / \mathrm{d} \text { in } 2 \text { divided doses }\end{array}$} & \multicolumn{3}{|c|}{$\begin{array}{l}\text { Placebo or conivaptan } \\
40 \text { or } 80 \mathrm{mg} / \mathrm{d} \text { in } 2 \text { divided doses }\end{array}$} & \multicolumn{3}{|c|}{$\begin{array}{l}\text { Placebo or } 20 \mathrm{mg} \text { of conivaptan as a } \\
\text { bolus iv dose, followed by a continuous } \\
\text { infusion of } 40 \text { or } 80 \mathrm{mg} / \mathrm{d}\end{array}$} \\
\hline Duration of treatment & \multicolumn{3}{|l|}{5 days } & \multicolumn{3}{|l|}{5 days } & \multicolumn{3}{|l|}{4 days } \\
\hline Primary endpoint & Placebo & $\begin{array}{l}40 \mathrm{mg} / \mathrm{d} \\
(P)\end{array}$ & $\begin{array}{l}80 \mathrm{mg} / \mathrm{d} \\
(P)\end{array}$ & Placebo & $\begin{array}{l}40 \mathrm{mg} / \mathrm{d} \\
(P)\end{array}$ & $\begin{array}{l}80 \mathrm{mg} / \mathrm{d} \\
(P)\end{array}$ & Placebo & $\begin{array}{l}40 \mathrm{mg} / \mathrm{d} \\
(P)\end{array}$ & $\begin{array}{l}80 \mathrm{mg} / \mathrm{d} \\
(P)\end{array}$ \\
\hline $\begin{array}{l}\text { LS mean change from } \\
\text { baseline in serum }\left[\mathrm{Na}^{+}\right] \\
\text {AUC during the } 5 \text {-day } \\
\text { treatment } \pm \mathrm{SE}(\mathrm{mEq} \mathrm{h} / \mathrm{L})\end{array}$ & 309.2 & $\begin{array}{l}621.3 \\
(0.03)\end{array}$ & $\begin{array}{l}836.2 \\
(<0.001)\end{array}$ & $88 \pm 81$ & $\begin{array}{l}634 \pm 84 \\
(0.000 I)\end{array}$ & $\begin{array}{l}953 \pm 86 \\
(0.000 I)\end{array}$ & 12.9 & $\begin{array}{l}490.9 \\
(<0.001)\end{array}$ & $\begin{array}{l}716.6 \\
(<0.001)\end{array}$ \\
\hline Secondary endpoints & Placebo & $\begin{array}{l}40 \mathrm{mg} / \mathrm{d} \\
(P)\end{array}$ & $\begin{array}{l}80 \mathrm{mg} / \mathrm{d} \\
(P)\end{array}$ & Placebo & $\begin{array}{l}40 \mathrm{mg} / \mathrm{d} \\
(P)\end{array}$ & $\begin{array}{l}80 \mathrm{mg} / \mathrm{d} \\
(P)\end{array}$ & Placebo & $\begin{array}{l}40 \mathrm{mg} / \mathrm{d} \\
(P)\end{array}$ & $\begin{array}{l}80 \mathrm{mg} / \mathrm{d} \\
(P)\end{array}$ \\
\hline $\begin{array}{l}\text { Time to a confirmed } \\
\text { increase in serum }\left[\mathrm{Na}^{+}\right] \\
\geq 4 \mathrm{mEq} / \mathrm{L} \text { from baseline } \\
\text { (median } \mathrm{h} \text { ) }\end{array}$ & 71.7 & $\begin{array}{l}27.5 \\
(0.044)\end{array}$ & $\begin{array}{l}12.1 \\
(0.002)\end{array}$ & - & $\begin{array}{l}23.5 \\
(0.0004)\end{array}$ & $\begin{array}{l}8.7 \\
(0.0001)\end{array}$ & - & $\begin{array}{l}23.7 \\
(<0.001)\end{array}$ & $\begin{array}{l}23.4 \\
(<0.001)\end{array}$ \\
\hline $\begin{array}{l}\text { Total time serum } \\
{\left[\mathrm{Na}^{+}\right] \geq 4 \mathrm{mEq} / \mathrm{L} \text { above }} \\
\text { baseline }[\mathrm{LS} \text { mean }(\mathrm{SE}) \cdot \mathrm{h}]\end{array}$ & 46.5 & $\begin{array}{l}69.8 \\
(0.103)\end{array}$ & $\begin{array}{l}88.8 \\
(0.001)\end{array}$ & 20.3 & $\begin{array}{l}68.8 \\
(0.000 I)\end{array}$ & $\begin{array}{l}86.6 \\
(0.0001)\end{array}$ & 14.2 & $\begin{array}{l}53.2 \\
(<0.001)\end{array}$ & $\begin{array}{l}72.7 \\
(<0.00 \mathrm{I})\end{array}$ \\
\hline $\begin{array}{l}\text { Change in serum }\left[\mathrm{Na}^{+}\right] \text {to } \\
\text { end of treatment } \\
{[\mathrm{LS} \text { mean }(\mathrm{SE}) \mathrm{mEq} / \mathrm{L}]}\end{array}$ & 3.4 & $\begin{array}{l}6.4 \\
(0.08 I)\end{array}$ & $\begin{array}{l}8.2 \\
(0.002)\end{array}$ & 1.6 & $\begin{array}{l}7.2 \\
(0.000 I)\end{array}$ & $\begin{array}{l}9.1 \\
(0.0001)\end{array}$ & 0.8 & $\begin{array}{l}6.3 \\
(<0.001)\end{array}$ & $\begin{array}{l}9.4 \\
(<0.00 \mathrm{I})\end{array}$ \\
\hline $\begin{array}{l}\text { Patients with a confirmed } \\
\text { normal serum }\left[\mathrm{Na}^{+}\right] \\
\text {( } \geq 135 \mathrm{mEq} / \mathrm{L}) \\
\text { or increase of } \geq 6 \mathrm{mEq} / \mathrm{L} \\
\text { [no. (\%)] }\end{array}$ & II & $\begin{array}{l}17 \\
(0.111)\end{array}$ & $\begin{array}{l}22 \\
(0.014)\end{array}$ & 20 & $\begin{array}{l}66.7 \\
(0.0008)\end{array}$ & $\begin{array}{l}88.5 \\
(<0.000 \mathrm{I})\end{array}$ & 20.7 & $\begin{array}{l}69 \\
(<0.001)\end{array}$ & $\begin{array}{l}23 \\
(<0.00 \mathrm{I})\end{array}$ \\
\hline
\end{tabular}

63.5 years and $63 \%$ were males. The mean left ventricular ejection fraction was $29.5 \%$ and $91 \%$ had NYHA class III and IV heart failure. Patients were randomized to receive $20 \mathrm{mg}$ conivaptan or placebo loading dose, followed by 40,80 , or $120 \mathrm{mg} /$ day conivaptan or placebo by continuous iv infusion for 2 days. Despite the increase in total urine output $(P<0.02)$ and the trend for a decrease in body weight), patient-assessed severity of respiratory symptoms did not improve.
A pooled analysis of a randomized controlled trial ${ }^{61}$ and an open-label trial ${ }^{62}$ evaluated the efficacy and safety of conivaptan in 335 patients with euvolemic or hypervolemic hyponatremia with or without underlying heart failure. Conivaptan (20 mg loading dose followed by 4-day continuous infusion of 40 or $80 \mathrm{mg} /$ day in the randomized controlled trial and 20 or $40 \mathrm{mg} /$ day in the open-label trial) produced prompt but controlled increases in serum $\left[\mathrm{Na}^{+}\right]$ 


\begin{tabular}{|c|c|c|c|c|c|c|c|c|c|}
\hline \multirow{2}{*}{\multicolumn{2}{|c|}{$\begin{array}{l}\text { Verbalis et al }{ }^{62} \\
251\end{array}$}} & \multicolumn{8}{|c|}{ Ghali et al $^{73}$} \\
\hline & & HF 98 & & & & No HF 23 & & & \\
\hline \multirow{2}{*}{\multicolumn{2}{|c|}{-}} & Placebo & $20 \mathrm{mg}$ & $40 \mathrm{mg}$ & $80 \mathrm{mg}$ & Placebo & $20 \mathrm{mg}$ & $40 \mathrm{mg}$ & $\begin{array}{l}80 \mathrm{mg} \\
\text { (Whites) }\end{array}$ \\
\hline & & 78 & 90 & 83 & 63 & 95 & 85 & 92 & 78 \\
\hline \multicolumn{2}{|l|}{-} & 44 & 60 & 54 & 38 & 50 & 67 & 70 & 50 \\
\hline \multicolumn{2}{|c|}{-} & 89 & 80 & 79 & 63 & 90 & 89 & 74 & 78 \\
\hline \multicolumn{2}{|l|}{-} & 75.7 & 69 & 73.1 & 70.8 & 75.7 & 75.1 & 71.7 & 73.7 \\
\hline \multicolumn{10}{|l|}{-} \\
\hline \multicolumn{2}{|l|}{ Open label } & \multicolumn{8}{|c|}{ Double-blind placebo-controlled $(n=184)$ open label $(n=25 I)$} \\
\hline \multicolumn{2}{|l|}{ iv } & \multicolumn{8}{|l|}{ iv } \\
\hline \multicolumn{2}{|c|}{$\begin{array}{l}\text { Loading dose of iv conivaptan } 20 \mathrm{mg} \text { followed by } \\
\text { a continuous iv infusion of conivaptan } \\
20 \text { or } 40 \mathrm{mg} / \mathrm{d}\end{array}$} & Loading $\mathrm{d}$ & se of $20 \mathrm{mg}$ & followed by & ontinous in & usion 40 or & $80 \mathrm{mg} / \mathrm{d}$ & & \\
\hline \multicolumn{2}{|l|}{4 days } & \multicolumn{4}{|l|}{4 days } & \multicolumn{4}{|l|}{4 days } \\
\hline $20 \mathrm{mg} / \mathrm{d}$ & $80 \mathrm{mg} / \mathrm{d}$ & Placebo & $20 \mathrm{mg} / \mathrm{d}$ & $40 \mathrm{mg} / \mathrm{d}$ & $80 \mathrm{mg} / \mathrm{d}$ & Placebo & $20 \mathrm{mg} / \mathrm{d}$ & $40 \mathrm{mg} / \mathrm{d}$ & $80 \mathrm{mg} / \mathrm{d}$ \\
\hline 753.8 & 689.2 & 93 & 459.0 & 579.0 & 576.0 & 47.0 & 867.0 & 703.0 & 700.0 \\
\hline $20 \mathrm{mg} / \mathrm{d}$ & $80 \mathrm{mg} / \mathrm{d}$ & Placebo & $20 \mathrm{mg} / \mathrm{d}$ & $40 \mathrm{mg} / \mathrm{d}$ & $80 \mathrm{mg} / \mathrm{d}$ & Placebo & $20 \mathrm{mg} / \mathrm{d}$ & $40 \mathrm{mg} / \mathrm{d}$ & $80 \mathrm{mg} / \mathrm{d}$ \\
\hline- & - & NE & 30.0 & 28.0 & 24.0 & NE & 18.0 & 24.0 & 8.0 \\
\hline- & - & & & & & & & & \\
\hline- & - & 3.0 & 7.9 & 7.9 & 9.0 & 3.1 & 9.8 & 8.1 & 9.4 \\
\hline - & - & 11 & 50 & 63 & 88 & 25 & 78 & 75 & 89 \\
\hline
\end{tabular}

Abbreviations: AUC, area under the curve; iv, intravenous; $\mathrm{HF}$, heart failure; $\mathrm{NE}$, not estimable.

that were often evident by the end of day 1 of treatment. By the end of treatment most conivaptan-treated patients with or without heart failure achieved $\mathrm{a} \geq 6 \mathrm{mEq} / \mathrm{L}$ increase in serum $\left[\mathrm{Na}^{+}\right]$above baseline or a normal serum $\left[\mathrm{Na}^{+}\right]$concentration $(\geq 135 \mathrm{mEq} / \mathrm{L})$.

Patients with heart failure demonstrated a lower increase in serum $\left[\mathrm{Na}^{+}\right] \mathrm{AUC}$, a longer time to a confirmed $\geq 4 \mathrm{mEq} / \mathrm{L}$ increase in serum $\left[\mathrm{Na}^{+}\right]$, and a lower likelihood of $\mathrm{a} \geq 6 \mathrm{mEq} / \mathrm{L}$ increase in serum $\left[\mathrm{Na}^{+}\right]$or a normal serum $\left[\mathrm{Na}^{+}\right]$compared to those without heart failure.

Another issue that has not been adequately addressed is fluid restriction. On one hand, adherence to strict fluid restriction may result in hypernatremia but on the other, liberalization of fluid intake may limit the extent of fluid removal in patients with decompensated heart failure and fluid overload. 
Table 6 Effect of conivaptan on myocardial cells hemodynamics in heart failure animals

\begin{tabular}{|c|c|c|c|c|}
\hline References & Species & Condition of species & Intervention & Results \\
\hline Tahara et a ${ }^{65}$ & $\begin{array}{l}\text { Neonatal rat } \\
\text { cardiomyocytes } \\
\text { (Wistar rats) }\end{array}$ & Cultured cells & YM087 (conivaptan) & $\begin{array}{l}\text { Dose dependent inhibition of AVP induced } \\
\text { protein synthesis }\end{array}$ \\
\hline Tahara et al ${ }^{66}$ & $\begin{array}{l}\text { Rat vascular } \\
\text { smooth muscle } \\
\text { cells }\end{array}$ & Cultured cells & YM087 (conivaptan) & $\begin{array}{l}\text { Prevented AVP-induced hyperplasia and } \\
\text { hypertrophy of these cells in concentration } \\
\text { dependent manner }\end{array}$ \\
\hline Yatsu et $a^{167}$ & $\begin{array}{l}\text { Dogs }(n=8) \\
\text { (male and female } \\
\text { Beagle) }\end{array}$ & $\begin{array}{l}\text { Pacing-induced HF } \\
\text { Anesthetized }\end{array}$ & Vehicle or $0.1 \mathrm{mg} / \mathrm{kg}$ iv conivaptan & $\begin{array}{l}\text { Increased cardiac output and stroke } \\
\text { volume, reduced LVEDP and TPR, increased } \\
\text { urine flow and decreased urine osmolarity }\end{array}$ \\
\hline Yatsu et $\mathrm{a}^{68}$ & $\begin{array}{l}\text { Dogs }(\mathrm{n}=\mathrm{II}) \\
\text { (male and female } \\
\text { mongrel dogs) }\end{array}$ & $\begin{array}{l}\text { Normal } \\
\text { Anesthetized }\end{array}$ & $\begin{array}{l}\text { AVP infusion followed by iv bolus of } \\
0.9 \% \text { saline followed by } 0.1 \mathrm{mg} / \mathrm{kg} \text { iv } \\
\text { conivaptan }\end{array}$ & $\begin{array}{l}\text { Rapidly attenuated the AVP induced } \\
\text { decrease in CO and reversed the AVP } \\
\text { induced elevation in both LVEDP and TPR }\end{array}$ \\
\hline Wada et al ${ }^{69}$ & Rats & $\begin{array}{l}\text { Ml-induced HF } \\
(\mathrm{n}=30) \\
\text { Conscious } \\
\text { vs } \\
\text { Sham operated control } \\
\text { rats } \\
\text { Conscious }\end{array}$ & $\begin{array}{l}\text { Aquaretic effect: }(\mathrm{n}=30) \\
\text { Vehicle or } 0.03,0.1,0.3 \mathrm{mg} / \mathrm{kg} \text { iv conivaptan } \\
\text { Or } 0.3 \mathrm{mg} / \mathrm{kg} \mathrm{V}_{2} \mathrm{R} \text { antagonist SR I2 I } 463 \mathrm{~A} \\
\text { Hemodynamic effect: }(\mathrm{n}=39) \\
\text { Vehicle or } 0.1,0.3 \mathrm{mg} / \mathrm{kg} \text { iv conivaptan } \\
\text { Or } 0.3 \mathrm{mg} / \mathrm{kg} \mathrm{V}_{2} \mathrm{R} \text { antagonist SR I } 2 \text { I } 463 \mathrm{~A}\end{array}$ & $\begin{array}{l}\text { Dose dependent increase in urine volume } \\
\text { and reduction of urine osmolality in both } \\
\mathrm{HF} \text { and sham-operated rats. SR I } 2 / 463 \mathrm{~A} \\
\text { had similar effects to conivaptan } \\
\text { Reduction of RV systolic and RA pressures, } \\
\text { LVEDP, lung and body weight. Increased } \\
\mathrm{dP} / \mathrm{dt}_{\text {max }} / \mathrm{LVP} \\
\mathrm{SR} / 2 \mathrm{I} 63 \mathrm{~A} \text { caused similar effects except it } \\
\text { did not improve } \mathrm{dP} / \mathrm{dt}_{\text {max }} / \mathrm{LVP}\end{array}$ \\
\hline \multirow[t]{2}{*}{ Wada et al ${ }^{70}$} & $\begin{array}{l}\text { Rats }(\mathrm{n}=19) \\
\text { (male Wistar) }\end{array}$ & $\begin{array}{l}\text { MI-induced HF } \\
\text { vs } \\
\text { Sham operated control } \\
\text { rats }\end{array}$ & $\begin{array}{l}\text { Aquaretic effect: } \\
\text { Vehicle or } 0.3 \text { to } 3 \mathrm{mg} / \mathrm{kg} \text { oral conivaptan } \\
\text { Hemodynamic effect: }\end{array}$ & $\begin{array}{l}\text { Higher AVP level in HF compared to sham } \\
\text { operated rats } \\
\text { Reduction of LVEDP, lung and RV weights } \\
\text { and reduced mean blood pressure. No } \\
\text { effect on heart rate or LV systolic pressure }\end{array}$ \\
\hline & & Conscious & Vehicle or $3 \mathrm{mg} / \mathrm{kg}$ oral conivaptan & $\begin{array}{l}\text { Conivaptan also increased urine volume } \\
\text { and reduced urine osmolarity }\end{array}$ \\
\hline
\end{tabular}

Abbreviations: AVP, arginine vasopressin peptide; CO, cardiac output; HF, heart failure; iv, intravenous; LV, left ventricle; LVP, left ventricular pressure; LVEDP, left ventricle end diastolic pressure; MI, myocardial infarction; RA, right atrium; RV, right ventricle; TPR, total peripheral resistance.

\section{Use of conivaptan in cirrhosis}

Cirrhosis, like heart failure, is characterized by dilutional hyponatremia, impaired water excretion and persistent inappropriate AVP elevation by non-osmotic mechanisms. There is limited information about the use of conivaptan in this setting. In one study in rats with cirrhosis, conivaptan has shown to increase urine volume and osmolarity without affecting arterial blood pressure and creatinine clearance. ${ }^{74}$ Theoretically, it may not be advisable to use conivaptan in patients with cirrhosis because of the possibility that $\mathrm{V}_{1 \mathrm{~A}}$ inhibition may result in splanchnic vasodilatation as well as interference with platelet aggregation, actions that may promote variceal bleeding. ${ }^{32}$

\section{Other uses of AVP receptor blockers Hyponatremia in the neurocritical care unit}

The use of conivaptan in correcting hyponatremia in patients admitted to neurointensive care units was reported in two retrospective studies. The first study in 22 patients with hyponatremia (defined as $\left[\mathrm{Na}^{+}\right]<136 \mathrm{mEq} / \mathrm{L}$ ) showed a very favorable response to conivaptan given as a bolus followed by infusion. An increase of $\geq 6 \mathrm{mEq} / \mathrm{L}$ was noted in $86 \%$ of the patients with an average time of 13.1 hours and no patient experienced rapid over correction. ${ }^{75}$ In another study, correction of hyponatremia was evaluated in 19 patients admitted to a neurointensive care unit with the administration of conivaptan 20 or $40 \mathrm{mg}$ bolus given over 30 minutes, and repeated bolus injections given 12 to 72 hours after the first with no subsequent infusion. Serum $\left[\mathrm{Na}^{+}\right]$increased by $5.8 \pm 3.2 \mathrm{mEq} / \mathrm{L}$ within 12 hours for an overall $71 \%$ response as defined by at least $4 \mathrm{mEq} / \mathrm{L}$ increase in serum $\left[\mathrm{Na}^{+}\right]$and $52 \%$ manifesting a $6 \mathrm{mEq} / \mathrm{L}$. An increase of $4 \mathrm{mEq} / \mathrm{L}$ was maintained for up to 72 hours in $69 \%$ of patients. ${ }^{76}$

\section{Tumor lysis syndrome}

Conivaptan was used to treat SIADH in a thirteen yearold patient with large-cell lymphoma before and during 


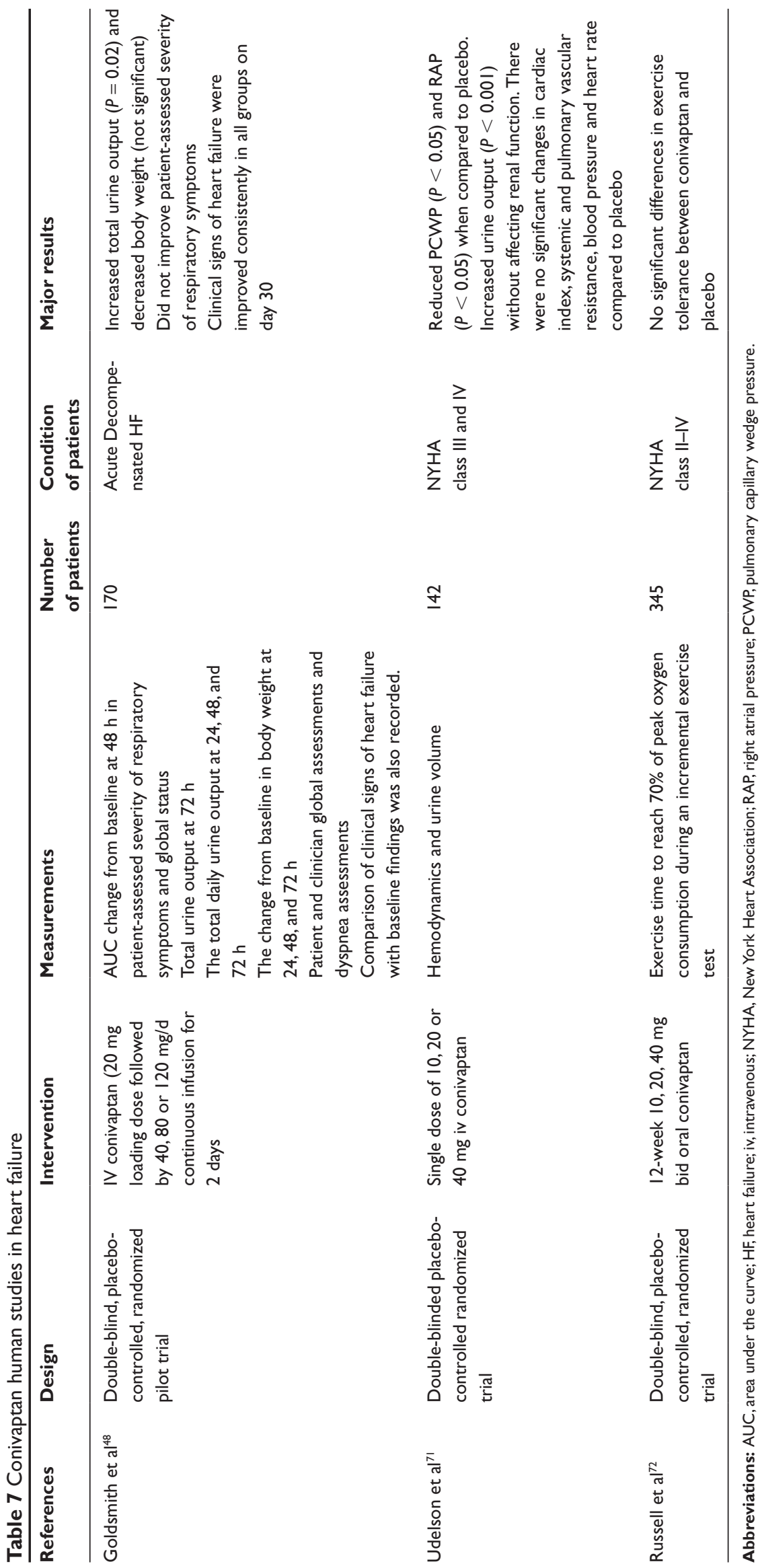


chemotherapy administration. This allowed aggressive hydration to prevent tumor lysis syndrome while inducing free-water excretion. ${ }^{77}$ Further studies are needed to assess the potential therapeutic use for conivaptan for this indication.

\section{Future use of conivaptan}

Conivaptan is distinguished from other VRAs by its antagonism of both $\mathrm{V}_{1 \mathrm{~A}}$ and $\mathrm{V}_{2}$ receptors; thus, in heart failure it offers a theoretical advantage by combining a potential of hemodynamic benefit and reverse remodeling in addition to diuresis. Experimentally, it has been demonstrated that combined antagonism of $\mathrm{V}_{1 \mathrm{~A}}$ and $\mathrm{V}_{2}$ receptors could induce more beneficial hemodynamic responses compared to antagonism of $\mathrm{V}_{1 \mathrm{~A}}$ receptors alone. ${ }^{78}$ Also, it is worth mentioning that in the single dose hemodynamic study, there was no correlation between urine output and the decrease in filling pressures suggesting the possibility of a salutary effect beyond diuresis. Furthermore, that study was carried on in stable patients with heart failure, therefore, the potential benefit of conivaptan in patients with acute decompensated heart failure, whether systolic or diastolic and particularly in those with hyponatremia has not been adequately explored and it should be further investigated.

The ability to administer conivaptan intravenously offers an opportunity to explore its usage in the treatment of symptomatic hyponatremia in combination with hypertonic saline. Considering the ease of use of single or multiple injections rather than continuous infusion, the efficacy of this modality of administration should also be investigated.

\section{Acknowledgments}

The authors would like to express their appreciation to: Pamela A McKinley, Administrative Assistant for secretarial assistance.

\section{Disclosures}

Dr Ghali has acted as a consultant for Astellas and Otsuka, and has received research grants from CardioKine Inc and Biogen Idec.

\section{References}

1. Upadhyay A, Jaber BL, Madias NE. Incidence and prevalence of hyponatremia. Am J Med. 2006;119:S30-S35.

2. Hawkins RC. Age and gender as risk factors for hyponatremia and hypernatremia. Clinica Chimica Acta. 2003;337:169-172.

3. Zilberberg MD, Exuzides A, Spalding J, Foreman A, et al. Epidemiology, clinical and economic outcomes of admission hyponatremia among hospitalized patients. Curr Med Res Opin. 2008;24:1601-1608.
4. Cleland JGF, Swedberg K, Follath F, et al. The EuroHeart Failure survey programme-a survey on the quality of care among patients with heart failure in Europe. Part 1: patient characteristics and diagnosis. Eur Heart J. 2003;24:442-463.

5. The study group of Diagnosis of the Working Group on Heart Failure of the European Society of Cardiology, Komajda M, Follath F, Swedberg K, Cleland J, Aguilar JC. The EuroHeart Failure survey programme - a survey on the quality of care among patients with heart failure in Europe. Part 2: treatment. Eur Heart J. 2003;24:464-474.

6. Tavazzi L, Maggioni AP, Lucci D, et al. Nationwide survey on acute heart failure in cardiology ward services in Italy. Eur Heart $J$. 2006;27:1207-1215.

7. Zannad F, Mebazaa A, Juillère Y, et al. Clinical profile, contemporary management and one-year mortality in patients with severe acute heart failure syndromes: The EFICA study. Eur J Heart Fail. 2006; 8:697-705.

8. Gheorghiade M, Abraham WT, Albert NM, et al. Relationship between admission serum sodium concentration and clinical outcomes in patients hospitalized for heart failure: an analysis from the OPTIMIZE-HF registry. Eur Heart J. 2007;28:980-988.

9. Ghali JK. Hyponatraemia in heart failure: a call for redefinition. Eur Heart J. 2007;28:921-921.

10. Ayus JC, Arieff AI. Abnormalities of water metabolism in the elderly. Semin Nephrol. 1996;16:277-288.

11. Adrogue HJ, Madias NE. Hyponatremia. N Engl J Med. 2000;342: 1581-1589.

12. Arieff AI, Llach F, Massry SG. Neurological manifestations and morbidity of hyponatremia: correlation with brain water and electrolytes. Medicine (Baltimore). 1976;55:121-129.

13. Arieff AI, Guisado R. Effects on the central nervous system of hypernatremic and hyponatremic states. Kidney Int. 1976;10:104-116.

14. Adrogué HJ, Wesson DE. Salt and Water in Hyponatremia and Hypernatremia. Boston: Blackwell Scientific; 1994:205-284.

15. Weisberg LS. Pseudohyponatremia: a reappraisal. Am J Med. 1989;86:315-318.

16. Aw TC, Kiechle FL. Pseudohyponatremia. Am J Emerg Med. 1985;3: 236-239.

17. Charles E Wade, Lanny C, Keil David J. Ramsay. Role of volume and osmolality in the control of plasma vasopressin in dehydrated dogs. Neuroendocrinology. 1983;37:349-353.

18. Leaf A, Mamby AR. An antidiuretic mechanism not regulated by extracellular fluid toxicity. $J$ Clin Invest. 1952;31:60-71.

19. Weston RE, Grossman J, Borun ER, Hanenson IB. The pathogenesis and treatment of hyponatremia in congestive heart failure. Am J Med. 1858;25:558-572.

20. Burbach JP, Luckman SM, Murphy D, Gainer H. Gene regulation in the magnocellular hypothalamo-neurohypophysial system. Physiol Rev. 2001;81:1197-1267.

21. Oliet SH, Bourque CW. Mechanosensitive channels transduce osmosensitivity in supraoptic neurons. Nature. 1993;364:341-343.

22. Bourque CW, Oliet SH. Osmoreceptors in the central nervous system. Annu Rev Physiol. 1997;59:601-619.

23. McKinley MJ, Denton DA, Oldfield BJ, De Oliveira LB, Mathai ML. Water intake and the neural correlates of the consciousness of thirst. Semin Nephrol. 2006;26:249-257.

24. Schrier RW. Water and sodium retention in edematous disorder: role of vasopressin and aldosterone. Am J Med. 2006;119:S47-S53.

25. Mitchell LD, Barron K, Brody MJ, Johnson AK. Two possible actions for circulating angiotensin II in the control of vasopressin release. Peptides. 1982;3:503-507.

26. Brooks VL, Keil LC, Reid IA. Role of the renin-angiotensin system in the control of vasopressin secretion in conscious dogs. Circ Res. 1986;58:829-838.

27. Hoorn EJ, Zietse R. Hyponatremia revisited: translating physiology to practice. Nephron Physiol. 2008;108:46-59.

28. Coyle S, Penney MD, Masters PW, Walker BE. Early diagnosis of ectopic arginine vasopressin secretion. Clin Chem. 1993;39:152-154. 
29. Nielsen S. Frøkler J, Marples D, Kwon T, Agre P, Knepper MA. Aquaporins in the kidney from molecules to medicine. Physiol Rev. 2002;82:205-244.

30. Fujiwara TM, Bichet DG. Molecular biology of hereditary diabetes insipisus. J Am Soc Nephrol. 2005;16:2836-2846.

31. Thibonnier M, Conarty DM, Preston JA, Wilkins PL, Berti-Mattera LN, Mattera R. Molecular pharmacology of human vasopressin receptors. Adv Exp Med Biol. 1998;449:251-276.

32. Ali F, Guglin M, Vaitkevicius P, Ghali JK. Therapeutic potential of vasopressin receptor antagonists. Drugs. 2007;67:847-858.

33. Young WS, Li J, Wersinger SR, Palkovits M. The vasopressin 1B receptor is prominent in the hippocampal area CA2 where it is unaffected by restraint stress or adrenalectomy. Neuroscience. 2006;143. 1031-1039.

34. Folny V, Raufaste D, Lukovic L, et al. Pancreatic vasopressin $V_{1 B}$ receptors: characterization in In-R1-G9 cells and localization in human pancreas. Am J Physiol Endocrinol Metab. 2003;285:E566-E567.

35. Antoni, FA. Vasopressinergic control of pituitary adrenocorticotropin secretion comes of age. Front Neuroendocrinol. 1993;14:76-122.

36. Tanoue $\mathrm{A}$, Ito $\mathrm{S}$, Honda $\mathrm{K}$, et al. The vasopressin $\mathrm{V}_{1 \mathrm{~B}}$ receptor critically regulates hypothalamic-pituitary-adrenal axis activity under both stress and resting conditions. J Clin Invest. 2004;113:302-309.

37. Suzuki S, Takeshita A, Imaizumi T, et al. Biphasic forearm vascular responses to intraarterial arginine vasopressin. J Clin Invest. 1989;84: 427-434.

38. Bankir L. Antidiuretic action of vasopressin: quantitative aspects and interaction between $\mathrm{V}_{1 \mathrm{~A}}$ and $\mathrm{V}_{2}$ receptor-mediated effects. Cardiovasc Res. 2001;51:372-390.

39. Verbalis JG . Vasopressin $\mathrm{V}_{2}$ receptor antagonists. J Mol Endocrinol. 2002;29:1-9

40. Yamamura Y, Ogawa H, Ghihara T, et al. OPC-21268, an orally effective, nonpeptide vasopressin $\mathrm{V}_{1}$ receptor antagonist. Science. 1991;252:572-574.

41. Ghali JK. Mechanisms, risks and new treatment options for hyponatremia. Cardiology. 2008;111:147-157.

42. Verbalis JG, Goldsmith SR, Greenberg A, Schrier RW, Sterns RH Hyponatremia treatment guidelines 2007: expert panel recommendations. Am J Med. 2007;120(11 Suppl 1):S1-S21.

43. Ali F, Raufi A, Washington B, Ghali JK. Conivaptan: A dual receptor vasopressin $\mathrm{V}_{1 \mathrm{~A}} / \mathrm{V}_{2}$ antagonist. Cardiovasc Drug Rev. 2007;25: 261-279.

44. Risvanis J, Naitoh M, Johnston CI, Burrell LM. In vivo and in vitro characterization of a nonpeptide vasopressin $\mathrm{V}_{1 \mathrm{~A}}$ and $\mathrm{V}_{2}$ receptor antagonist (YM087) in the rat. Eur J Pharmacol. 1999;381:23-30.

45. Tahara A, Tomura Y, Wada KI, et al. Pharmacological profile of YM087, a novel potent nonpeptide vasopressin $\mathrm{V}_{1}$ and $\mathrm{V}_{2}$ receptor antagonist, in vitro and in vivo. J Pharmacol Exp Ther. 1997;282:301-308.

46. Burnier M, Fricker AF, HayozD, Nussberger J, Brunner HR. Pharmacokinetic and pharmacodynamic effects of YM087, a combined $\mathrm{V}_{1} / \mathrm{V}_{2}$ vasopressin receptor antagonist in normal subjects. Eur J Clin Pharmacol. 1999;55:633-637.

47. Vaprisol [package insert]. Deerfield, IL: Astellas Pharma US, Inc., 2006.

48. Goldsmith SR, Elkayam U, Haught WH, Barve A, He W. Efficacy and safety of the vasopressin $\mathrm{V}_{1 \mathrm{~A}} / \mathrm{V}_{2}$-receptor antagonist conivaptan in acute decompensated heart failure: a dose-ranging pilot study. J Card Fail. 2008;14:641-647.

49. Vaprisol (Conivaptan Hcl Injection) Drug information: uses, side effects, drug interactions), December 2008, www.rxlist.com/vaprisol-drug.htm, Accessed August 25, 2009.

50. Sterns RH, Cappuccio JD, Silver SM, Cohen EP. Neurologic sequelae after treatment of severe hyponatremia: a multicenter perspective. J Am Soc Nephrol. 1994;4:1522-1530.

51. Strange K. Regulation of solute and water balance and cell volume in the central nervous system. J Am Soc Nephrol. 1992;3:12-27.

52. Ausiello DA, Skorecki KL, Verkman AS, Bonventre JV. Vasopressin signaling in kidney cells. Kidney Int. 1987;31:521-529.
53. Lien YH, Shapiro JI, Chan L. Study of brain electrolytes and organic osmolytes during correction of chronic hyponatremia. Implications for the pathogenesis of central pontine myelinolysis. $J$ Clin Invest. 1991;88:303-309.

54. Melton JE, Patlak CS, Pettigrew KD, Cserr HF. Volume regulatory loss of $\mathrm{Na}, \mathrm{Cl}$, and $\mathrm{K}$ from rat brain during acute hyponatremia. Am J Physiol. 1987;252:F661-F669.

55. Verbalis JG, Gullans SR. Hyponatremia causes large sustained reductions in brain content of multiple organic osmolytes in rats. Brain Res. 1991;567:274-282.

56. Yatsu T, Tomura Y, Tahara A, et al. Pharmacological profile of YM087, a novel nonpeptide dual vasopressin $\mathrm{V}_{1 \mathrm{~A}}$ and $\mathrm{V}_{2}$ receptor antagonist, in dogs. Eur J Pharmacol. 1997;321:225-230.

57. Tomura Y, Tahara A, Tsukada J, et al. Pharmacological profile of orally administered YM087, a vasopressin antagonist, in conscious rats. Clin Exp Pharmacol Physiol. 1999;26:399-403.

58. Wada K, Matsukawa U, Fujimori A, et al. A novel vasopressin dual $\mathrm{V}_{1 \mathrm{~A}} / \mathrm{V}_{2}$ receptor antagonist, conivaptan hydrochloride, improves hyponatremia in rats with syndrome of inappropriate secretion of antidiuretic hormone (SIADH). Biol Pharm Bull. 2007;30:91-95.

59. Ghali JK, Koren MJ, Taylor JR, et al. Efficacy and safety of oral conivaptan: a $\mathrm{V}_{1 \mathrm{~A}} / \mathrm{V}_{2}$ vasopressin receptor antagonist, assessed in a randomized, placebo-controlled trial in patients with euvolemic or hypervolemic hyponatremia. J Clin Endocrinol Metab. 2006;91: $2145-2152$.

60. Annane Djillali MD, Decaux Guy PhD, Smith Neila MD; for the Conivaptan Study Group, Efficacy and safety of oral conivaptan, a vasopressin-receptor antagonist, evaluated in a randomized, controlled trial in patients with euvolemic or hypervolemic hyponatremia. Am J Med Sci. 2009;337:28-36.

61. Zeltser D, Rosansky S, van Rensburg H, Verbalis JG, Smith N; Conivaptan study group. Assessment of the efficacy and safety of intravenous conivaptan in euvolemic and hypervolemic hyponatremia. Am J Nephrol. 2007;27:447-457.

62. Verbalis JG, Rosansky S, Wagoner LE, Smith N, Brave A, Andoh M. Conivaptan for the treatment of hyponatremia in hospitalized patients: results from an open label study. Crit Care Med. 2007;35(Suppl):A64 [abstract 242].

63. Fukuzawa J, Haneda T, Kikuchi K. Arginine vasopressin increases the rate of protein synthesis in isolated perfused adult rat heart via the $\mathrm{V}_{1}$ receptor. Mol Cell Biochem. 1999;195:93-98.

64. Nakamura Y, Haneda T, Osakie J, Miyata S, Kikuchi K. Hypertrophic growth of cultured neonatal rat heart cells mediated by vasopressin $V_{1 \mathrm{~A}}$ receptor. Eur J Pharmacol. 2000;39:39-48.

65. Tahara A, Tomura Y, Wada KI, et al. Effect o fYM087, a potent nonpeptide vasopressin antagonist, on vasopressin-induced protein synthesis in neonatal rat cardiomyocyte. Cardiovasc Res. 1998;38: 198-205.

66. Tahara A, Tomura Y, Wada K, et al. Effect of YM087, a potent nonpeptide vasopressin antagonist, on vasopressin-induced hyperplasia and hypertrophy of cultured vascular smooth-muscle cells. $J$ Cardiovasc Pharmacol. 1997;30:759-766.

67. Yatsu T, Tomura Y, Tahara A, et al. Cardiovascular and renal effects of conivaptan hydrochloride (YM087), a vasopressin $\mathrm{V}_{1 \mathrm{~A}}$ and $\mathrm{V}_{2}$ receptor antagonist, in dogs with pacing-induced congestive heart failure. Eur $J$ Pharmacol. 1999;376:239-246.

68. Yatsu T, Kusayama T, Tomura Y, et al. Effect of conivaptan, a combined vasopressin $\mathrm{V}_{1 \mathrm{~A}}$ and $\mathrm{V}_{2}$ receptor antagonist, on vasopressin-induced cardiac and haemodynamic changes in anaesthetized dogs. Pharmacol Res. 2002;46:375-381.

69. Wada K, Fujimori A, Matsukawa U, et al. Intravenous administration of conivaptan hydrochloride improves cardiac hemodynamics in rats with myocardial infarction-induced congestive heart failure. Eur $J$ Pharmacol. 2005;507:145-151.

70. Wada K, Tahara A, Arai Y, et al. Effect of the vasopressin receptor antagonist conivaptan in rats with heart failure following myocardial infarction. Eur J Pharmacol. 2002;450:169-177. 
71. Udelson JE, Smith WB, Hendrix GH, et al. Acute hemodynamic effects of conivaptan, a dual $\mathrm{V}_{1 \mathrm{~A}}$ and $\mathrm{V}_{2}$ vaspressin receptor antagonist, in patients with advanced heart failure. Circulation. 2001; 104:2417-2423.

72. Russell SD, Selaru P, Pyne DA, et al. Rationale for use of an exercise end point and design for the ADVANCE (A Dose evaluation of a Vasopressin ANtagonist in CHF patients undergoing Exercise) trial. Am Heart J. 2003;145:179-186.

73. Ghali JK, Yan B, McNutt B. Conivaptan, a vasopressin-receptor antagonist, for the treatment of hyponatremia in patients with and without underlying heart failure. J Card Fail. 2008;14(Suppl 1):236.

74. Fernández-Varo G, Ros J, Cejudo-Martín P, et al. Effect of the $\mathrm{V}_{1 \mathrm{~A}} / \mathrm{V}_{2}$ AVP receptor antagonist, Conivaptan, on renal water metabolism and systemic hemodynamics in rats with cirrhosis and ascites. $J$ Hepatol. 2003;38:755-761.
75. Wright WL, Asbury WH, Gilmore JL, Samules OB. Conivaptan for hyponatremia in the neurocritical care unit. Neurocrit Care. 2009; 11:6-13.

76. Murphy T, Dhar R, Diringer M. Conivaptan bolus dosing for the correction of hyponatremia in the neurointensive care unit. Neurocrit Care. 2009;11:14-19.

77. Rianthavorn P, Cain JP, Turman MA. Use of conivaptan to allow aggressive hydration to prevent tumor lysis syndrome in a pediatric patient with large-cell lymphoma and SIADH. Pediatr Nephrol. 2008;23:1367-1370.

78. Naitoh M, Suzuki H, Murakami M, et al. Effects of oral AVP receptor antagonists OPC-21268 and OPC-31260 on congestive heart failure in conscious dogs. Am J Physiol Heart Circ Physiol. 1994;267: $\mathrm{H} 2245-\mathrm{H} 2254$.

\section{Publish your work in this journal}

Drug Design, Development and Therapy is an international, peerreviewed open-access journal that spans the spectrum of drug design and development through to clinical applications. Clinical outcomes, patient safety, and programs for the development and effective, safe, and sustained use of medicines are a feature of the journal, which has also been accepted for indexing on PubMed Central. The manuscript management system is completely online and includes a very quick and fair peer-review system, which is all easy to use. Visit http://www.dovepress.com/testimonials.php to read real quotes from published authors.

Submit your manuscript here: http://www.dovepress.com/drug-design-development-and-therapy-journal 